\title{
Advantages of Lasers in Implantology
}

\author{
Kanwaldeep Singh Soodan ${ }^{1 *}$, Harjit Singh Kalsi ${ }^{2}$ and Pratiksha Priyadarshni ${ }^{3}$ \\ ${ }^{1}$ MM College of Dental Sciences and Research, India \\ ${ }^{2}$ Bharati Vidyapeeth Dental College, Mumbai, India \\ ${ }^{2}$ Dental Surgeon, India \\ *Corresponding author: Kanwaldeep Singh Soodan, Reader, MM College of Dental Sciences and Research, Mullana, Haryana,India
}

Submission: 眥 May 05, 2018 ; Published: 眥 July 05, 2018

\begin{abstract}
Implantology has become a treatment modality with high acceptance and success rate in the past few decades. Lasers were introduced into the field of clinical dentistry in 1986 with the hope of overcoming some of the drawbacks posed by the conventional dental procedures and in helping to solve some complications associated with the procedures. The two expanding aspects may be combined to provide the patients with a better clinical experience. Since its first dental application, the use of laser has increased rapidly in the last couple of decades. Their use in implant dentistry has seen a rapid growth in the past years. At present, wide varieties of procedures are carried out using lasers. Laser can be classified based on the wavelengths and tissue on which it acts. All available dental laser wavelengths cannot be used in every dental implant situation. The dentist must fully understand the characteristics, merits and demerits, and applicability of the available lasers. The aim of this article is to review the applications of lasers in implant dentistry.
\end{abstract}

Keywords: Dental implant; laser; Peri-implantitis; Photo sterilization

\section{Introduction}

LightAmplification by Stimulated Emission of Radiation (LASER) a device that transforms light of various frequencies into an intense, small, and nearly nondivergent beam of monochromatic radiation within the visible range. Lasers have been used for performing a variety of procedures, both in the medical and dental fields since its introduction by Maiman [13]; William \& Terry Myers [4] used a modified ophthalmic Neodynium: Yttrium Aluminum Garnet (Nd: YAG) laser for dental use in 1989. Lasers can be classified as soft tissue lasers and hard tissue lasers based on the tissue interaction. The soft tissue lasers include carbon dioxide $\left(\mathrm{CO}_{2}\right), \mathrm{Nd}$ : YAG, diode, argon, and holmium wavelengths whereas Erbium: YAG (Er: YAG) and Er: Yttrium scandiumgalliumgarnet (Er: YSGG) are hard tissue lasers. Their use can be either an adjunct to other procedures or the main form of treatment itself. Lasers have become the treatment of choice in various clinical situations as they could be used for both hard and soft tissue without anesthesia. Both implant dentistry and lasers in dentistry have evolved so much since its introduction and combining the two sought after treatment modalities can be beneficial for the dentist and the patient as well.

The advantages of using lasers in implant dentistry include
a) Increased hemostasis
b) Improved visibility of surgical site
c) Minimal damage to the surrounding tissue
d) Reduced swelling and

e) Decreased infection due to photo sterilization effect and in turn less pain postoperatively

The use of lasers depends on the situation to which it is applied and the particular wavelength suitable for that. The dentist should have thorough knowledge regarding the specific wavelength of laser that can be used in a particular procedure and also be aware of the lasertissue interactions that may result. Here, we discuss various applications of lasers in implant dentistry and the different wavelengths of lasers that may prove helpful.

\section{Implant placement}

Minimally invasive implant placement, using the tissue punch method, has become a popular way to place implants when proper bone height and width are available. Hard tissue lasers like Er: YAG can be used to obtain the initial breach for implant placement rather than using micromotor. A laser is used to remove the soft tissue and the cortical plate of bone in a circular pattern to approximately 2-3mm and rest of the osteotomy site can be prepared using a handpiece drill. Unlike conventional drills, the laser tip has fewer tendencies to slip.
a) This leads to
b) Quick healing time
c) Fast integration
d) Minimal patient discomfort and 


\section{e) Superior bonetoimplant contact}

This also eliminates the need for trauma during flap elevation and suture placement [5]. The procedure can be accomplished using a surgical guide prepared for laser placement of the implant. The advantages include a reduction in postoperative inflammation due to cleaner and sterile surgical field and better patient comfort. A study on rats by Kessler \& Koren [6] showed that there was significantly more bone contact and faster bone contact when comparing laser implant placement to implants placed with a conventional drill. However, the entire osteotomy site cannot be prepared using lasers, as the density of cortical bone varies in different regions of implant placement so the depth of Osteotomy is difficult to achieve with lasers alone.

\section{Uncovering implants in the second stage}

All wavelengths of laser can be used to Uncover Implants in stage II implant surgery with precision and ease for the practitioner and significant patient comfort by vaporizing the tissue overlying the implant till the surgical cap is reached [7]. The $\mathrm{CO}_{2}$ lasers and Er: YAG lasers are used with success while Nd: YAG laser is contraindicated as this causes temperature build up around the implants and also melting of the implant surface. This procedure is atraumatic and helps to prevent crestal bone remodeling [8-10]. Care must be taken to move the laser tip in a normal manner and not to hold in one location too long to avoid any heat buildup to the implant fixture. Furthermore, care is taken to maintain an adequate amount of attached gingiva around the implants. Laser treated tissue margins do not recede after healing. The laser is tipped at a $45^{\circ}$ angle toward the implant $[11,12]$.

The prime advantages of laser used in this procedure are

a) Hemostasis

b) Facilitate easier visual access to the cover screw

c) Production of a protective coaguluman aid to healing and patient comfort during and after treatment

d) It also allows impression procedures to be carried out in the same appointment

\section{Management of peri-implantitis}

$\mathrm{CO}_{2}$, the power output must be limited so as to avoid surface damage. The GAAlA laser did not cause any surface alterations. Photosterilization of compromised dental implant after debridement is done and the bone defect is grafted subsequently. Since laser surgery is bactericidal, infected implant sites can be relieved of pathogenic bacteria load and apical granulomas. Using scanning electron microscopy, Romanos et al. [13] investigated the attachment of osteoblasts to the titanium surface after $\mathrm{CO}_{2}$ and Er: YAG laser irradiation of the implant surface on four different types of autoclaved titanium disks with machined, hydroxyapatitecoated, sandblasted, or titanium plasmasprayed surfaces. All the implant surfaces examined were well colonized with osteoblasts. The study data showed that laser irradiation of titanium surfaces did not negatively influence osteoblast attachment and cell proliferation.
Lasers can also be used to debride extraction sites for immediate placement of implants.

\section{Implant explantation}

Increased use of dental implants has been followed with an increased rate of failing implants and the need for treatment [14]. Failing implants sometimes requires surgical removal using techniques such as block resection, buccal bone ostectomy, and trephine osteotomy $[15,16]$. "Failed implants" can be removed by using Er, chromium: YSGG (Er, Cr: YSGG) laser which provides a minimally invasive technique instead of conventional methods of removal. The Er, Cr: YSGG laser has been demonstrated to effectively cut bone without burning, melting or altering the calcium: phosphorus ratio of the irradiated bone [17]. The mechanism of cutting is through the laser energy being absorbed by the airwater spray which produces micro explosions on the target tissue. This hydrokinetic effect produces clean cuts without thermal damage. The decontamination effect of lasers may occur in the surrounding tissues during explanation and may promote uncomplicated tissue healing.

\section{Gingival Retraction}

The aim of gingival retraction is to a traumatically allow access for the impression material beyond the abutment margins and to create space so that the impression material is sufficiently thick to be tear resistant [18]. The mechanical retraction of gingival tissues using cords, which were developed for application around natural teeth, can lead to ulceration of the junctional epithelium when used around implant restorations. The forces used in cord placement may exceed periimplant tissues' capacity resulting in laceration of the sulcular epithelium and ulceration. There is a risk of permanent recession and loss of attachment developing. The use of mechanical retraction with cords may be contraindicated around implants, except in situations in which patients' sulcus depths are shallow with a healthy mucosa, and a thick gingival biotype is present.

The advantages of lasers in gingival retraction are excellent

a) Hemostasis $\left(\mathrm{CO}_{2}\right.$ laser is safe for implants as it is reflected by metal)

b) Reduced tissue shrinkage

c) Relatively painless procedure and sterilizes the sulcus

The use of Nd: YAG lasers are contraindicated near implant surfaces, as they absorb energy, and heat transmission to bone [4]. There is also a tendency for Nd: YAG lasers to damage the fragile subjunctional epithelium at the sulcus base around implants. Er: YAG lasers with a wavelength of $2,940 \mathrm{~nm}$ are reflected by metal implant surfaces and minimally penetrate the soft tissues, so they are relatively safe to use. The hemostasis achieved with the Er: YAG laser, however, is not as effective as that achieved with the $\mathrm{CO}_{2}$ laser [19]. In anterior areas where esthetics is critical, the effect can be traumatizing. Surgical wounds created by lasers heal by secondary intention, and incision lines show disorganized fibroblast alignment. This reduces tissue shrinkage through scarring, which 
helps preserve gingival margin heights [19]. Periimplant mucosa does not have the same capacity for regeneration as peridental mucosa. The correct use of lasers with appropriate wavelengths may be applicable.

\section{Laser micropatterning of dental implants}

Laser peening, which is a form of cold working, produces a surface with refined grain structures, compressive residual stresses, and increased hardness in metallic materials [2023]. This is done using precision laser micromachining (excimers or Nd: YAG laser) on implant surface which creates a controlled surface roughness and has shown to stimulate bone growth at the surface. Laser peening can achieve more significant surface enhancement than grit blasting [24]. The experiment conducted in a study showed that micropatterns of 20 micrometer wide and 7 micrometer deep imprinted on the biomedical implant material of cpTi through high energy pulsed laser peening was successful in creating a patterned surface and also improved the material mechanical strength. The patterned area appeared to have a significantly higher cell density than that on the untreated surface of the cpTi foil [25]. Higher removal torque values for laser micropatterned implants compared to machined implants were reported in several studies $[26,27]$.

\section{Gingival Contouring}

Gingival contouring of the soft tissue is desired or indicated before the preparation or impression; then, a laser is the instrument of choice to accomplish this procedure. Height or shape discrepancies can be easily corrected, and the gingival contours are maintained and the field can remain dry and clean, ready for impressions. The negligible tissue shrinkage after laser therapy is an advantage. Minor surgical correction of the gingival margin can be carried out, to assist adequate implant exposure or establish the correct emergence profile. The emergence profile of a restoration is the shape of the restoration in relation to the gingival tissues. Davarpanah et al. [28] proposed the emergence profile concept in implant therapy and a threestage approach to ensure that concept: implant stage, intermediate abutment stage, and definitive crown placement stage. The creation of a proper contoured restoration with a natural emergence profile and gingival architecture that harmonizes with the adjacent teeth is very important for esthetic and functional implant therapy [29].

\section{Laser welding of titanium components}

One of the hallmarks of the osseointegration technique is a passive fit of the prosthesis on the implants [30]. Laser welding can be advocated in fabricating frameworks to obtain a passive fit of implant prostheses on multiple implants. This eliminates the casting procedures and the consequences of expansioncontraction occurring during casting of the framework and the subsequent non-passivity of the framework. Bergendal \& Palmqvist [31] found that there was a tendency for more fractures of artificial teeth and acrylic resin in the titaniumwelded framework group. Riedy et al. [32] concluded that the laser welded framework exhibited a more precise fit than the onepiece casting.

\section{Computer-aided laser cured surgical template}

Presurgical planning is essential to obtain esthetic and functional implants, and a variety of techniques is presently available [33]. Surgically guided placement of implants is more accurate than freehand placement [34]. Rapid prototyping techniques allow the production of physical models on the basis of virtual computational models. The rapid prototyping technologies that are currently in use are stereolithography (SLA), inkjetbased system (3 dimensional printing), selective laser sintering (SLS), and fused deposition modeling. SLA uses an ultraviolet laser to "laser cure" crosssections of a liquid resin and is the technique which is commonly being used for the generation of computergenerated surgical guides [3537]. SLS models are opaque, whereas SLA models are translucent. [38] Fabrication of surgical templates using SLA have been proved to benefit from high precision by several welldocumented researches [37,3944].

\section{Low- level laser therapy/phototherapy/ photobiomodulation}

Also known as therapeutic lasers or Soft Lasers use sub thermal energy density in the Red wavelength $(1 \mathrm{~mW}-500 \mathrm{~mW})$. Therapeutic uses include postoperative care, tissue healing, reduced edema inflammation and pain. The bio-stimulatory effect of low level laser (LLL) was pioneered by Endre Mester in Budapest in the late 1960s, who demonstrated an increase in collagen synthesis in skin wounds. LLL therapy (LLLT) is based on biostimulation of the tissues with monochromatic light. After implant surgery, $1-5 \mathrm{j} / \mathrm{cm}^{2}$ energy twice weekly is used for soft tissue healing. Dörtbudak et al. [45] found that the use of lowlevel laser therapy with a diode soft laser $(690 \mathrm{~nm})$ for $60 \mathrm{~s}$ after the placement of toluidine blue 0 for $1 \mathrm{~min}$ on the contaminated surface reduced the counts of bacteria by a minimum of $92 \%$. However, complete elimination was not obtained. In implantology, LLLT seems to be a promising treatment to accelerate osseointegration, as demonstrated by its effects on bone repair $[46,47]$. Laser therapy improves bone matrix production because of the improved vascularization and antiinflammatory effects. The effect of LLLT on activation and increasing collagen production demonstrated by Kana et al. [48] can also lead to a better bone matrix for bone repair. Various in vitro and in vivo animal studies have shown that LLLT has got the potential of beneficial effects on the initial establishment of the implantbone interface [49] using GAAlA diode laser. Further investigations are needed as to the laser dosage for use in humans.

\section{Conclusion}

The use of lasers in implant dentistry has expanded and improved certain treatment options for clinicians who have adopted the technology. As with all dental materials and instruments, the practitioners must undergo proper training, before incorporation of laser technology in their practice. A wide variety of procedures can be performed in a painless and comfortable way using lasers. Lasers can be used for planning of implant placement, implant site preparation, second stage surgery of submerged implants, surgery to establish the health of soft tissue surrounding the implant and 
decontamination of titanium implant surfaces. The laser is an extremely useful piece of equipment for the implant dentistry and is rapidly becoming an essential component of modern implant practice. In the past few years, a wide spectrum of indications in implant dentistry has been proposed for laser systems.

\section{References}

1. Goldman L, Hornby P, Meyer R, Goldman B (1964) Impact of the laser on dental caries. Nature 203: 417

2. Frentzen M, Koort HJ (1990) Lasers in dentistry: New possibilities with advancing laser technology? Int Dent J 40(6): 323-332.

3. Walsh LJ (2003) The status of laser applications in dentistry. Aust Dent J 48(3): 146-155.

4. Martin E (2004) Lasers in dental implantology. Dent Clin North Am 48(4): 999-1015.

5. Eriksson AR, Albrektsson T (1983) Temperature threshold levels for heat-induced bone tissue injury: A vital-microscopic study in the rabbit J Prosthet Dent 50(1): 101-107.

6. Kesler G, Romanos G, Koren R (2006) Use of Er: YAG laser to improve osseointegration of titanium alloy implants-A comparison of bone healing. Int J Oral Maxillofac Implants 21(3): 375-379.

7. Kusek ER (2006) Use of the YSGG laser in dental implant surgery: Scientific rationale and case reports. Dent Today 25(10): 98.

8. Mombelli A (1997) Etiology, diagnosis, and treatment considerations in peri-implantitis. Curr Opin Periodontol 4: 127-136.

9. Leonhardt A, Renvert S, Dahlén G (1999) Microbial findings at failing implants. Clin Oral Implants Res10(5): 339-345.

10. Quirynen M, Marechal M, Busscher HJ, Weerkamp AH, Darius PL, et Al. (1990) The influence of surface free energy and surface roughness on early plaque formation. An in vivo study in man. J Clin Periodontol 17(3): 138-144.

11. Kreisler M, Kohnen W, Marinello C, Götz H, Duschner H, et al. (2002) Bactericidal effect of the Er: YAG laser on dental implant surfaces: An in vitro study. J Periodontol 73(11): 1292-1298.

12. Kreisler M, Götz H, Duschner H (2002) Effect of Nd:YAG, Ho:YAG, Er:YAG CO2, and GaAIAs laser irradiation on surface properties of endosseous dental implants. Int J Oral Maxillofac Implants 17(2): 202-211.

13. Romanos G, Crespi R, Barone A, Covani U (2006) Osteoblast attachment on titanium disks after laser irradiation. Int J Oral Maxillofac Implants 21(2): 232-236.

14. Levin L (1993) Dealing with dental implant failures. Refuat Hapeh Vehashinayim 27(1): 6-12.

15. Ten Bruggenkate CM, Sutter F, van den Berg JP, Oosterbeek HS (1994) Explanation procedure with special emphasis on the ITI implant system. Int J Oral Maxillofac Implants 9(2): 223-229.

16. Muroff FI (2003) Removal and replacement of a fractured denta implant: Case report. Implant Dent 12(3): 206-210.

17. Kimura Y, Yu DG, Fujita A, Yamashita A, Murakami Y, et al. (2001) Effects of erbium, chromium: YSGG laser irradiation on canine mandibular bone. J Periodontol 72(9): 1178-1182.

18. Wassell RW, Barker D, Walls AW (2002) Crowns and other extra-coronal restorations: Impression materials and technique. Br Dent J 192: 679690.

19. Parker S (2004) The use of lasers in fixed prosthodontics. Dent Clin North Am 48(4): 971-998.

20. Lu JZ, Luo KY, Zhang YK, Cui CY, Sun GF, et al. (2010) Grain refinement of
LY2 aluminum alloy induced by ultrahigh plastic strain during multiple laser shock processing impacts. Acta Mater 58(11): 3984-3994.

21. Lu JZ, Luo KY, Zhang YK, Sun GF, Gu YY, Zhou JZ, et al (2010) Grain refinement mechanism of multiple laser shock processing impacts on ANSI 304 stainless steel. Act Mater 58(16): 5354-5362.

22. Lu JZ, Zhong JW, Luo KY, Zhang L, Dai FZ, et al. (2011) Micro-structural strengthening mechanism of multiple laser shock processing impacts on AISI 8620 Steel. Mater Sci Eng A 528(19-20): 6128-6133.

23. Zhang XC, Zhang YK, Lu JZ, Xuan FZ, Wang ZD, et al. (2010) Improvement of fatigue life of Ti-6Al-4V alloy by laser shock peening. Mater Sci Eng A 527(15): 3411-3415.

24. Peyre P, Scherpereel X, Berthe L, Carboni C, Fabbro R, et al. (2000) Surface modifications induced in 316L steel by laser peening and shotpeening. Influence on pitting corrosion resistance. Mater Sci Eng A 280(2): 294-302.

25. Shen N, Ding H, Bowers R, Yu Y, Pence CN, et al. (2015) Surface micropatterning of pure titanium for biomedical applications via high energy pulse laser peening. J Micro Nano Manuf 3(1): 1-5.

26. Cho SA, Jung SK (2003) A removal torque of the laser-treated titanium implants in rabbit tibia. Biomaterials 24(26): 4859-4863.

27. Hallgren C, Reimers H, Chakarov D, Gold J, Wennerberg A (2003) An in vivo study of bone response to implants topographically modified by laser micromachining. Biomaterials 24(5): 701710.

28. Davarpanah M, Martinez H, Celletti R, Tecucianu JF (2001) Three-stage approach to aesthetic implant restoration: Emergence profile concept. Pract Proced Aesthet Dent 13(9): 761-767.

29. Wöhrle PS (2003) Nobel perfect esthetic scalloped implant: Rationale for a new design Clin. Implant Dent Relat Res 5 (Suppl 1): 64-73.

30. Branemark PI, Zarb GA, Albrektsson T (1985) Tissue-Integrated Prostheses: Osseo integration in Clinical Dentistry, Quintessence Publishing, Chicago, USA

31. Bergendal B, Palmqvist S (1995) Laser-welded titanium frameworks for fixed prostheses supported by osseointegrated implants: A 2-year multicenter study report. Int J Oral Maxillofac. Implants 10(2): 199-206.

32. Riedy SJ, Lang BR, Lang BE (1997) Fit of implant frameworks fabricated by different techniques. J. Prosthet Dent 78(6): 596-604.

33. Voitik AJ (2002) CT data and its CAD and CAM utility in implant planning: Part I. J Oral Implantol 28(6): 302-303.

34. Park C, Raigrodski AJ, Rosen J, Spiekerman C, London RM (2009) Accuracy of implant placement using precision surgical guides with varying occlusogingival heights: An in vitro study. J Prosthet Dent 101(6): 372-381.

35. D souza KM, Aras MA (2012) Applications of computer-aided design/ computer-assisted manufacturing technology in dental implant planning. J Dent Implant 2(1): 37-41.

36. Sohmura T, Kusumoto N, Otani T, Yamada S, Wakabayashi K, et al. (2009) CAD/CAM fabrication and clinical application of surgical template and bone model in oral implant surgery. Clin Oral Implants Res 20(1): 87-93.

37. Lal K, White GS, Morea DN, Wright RF (2006) Use of stereolithographic templates for surgical and prosthodontic implant planning and placement. Part I the concept J Prosthodont 15(2): 51-58.

38. Berry E, Brown JM, Connell M, Craven CM, Efford ND, et al. (1997) Preliminary experience with medical applications of rapid prototyping by selective laser sintering. Med Eng Phys 19(1): 90-96.

39. Sarment DP, Sukovic P, Clinthorne N (2003) Accuracy of implant placement with a stereolithographic surgical guide. Int J Oral Maxillofac Implants 18(4): 571-577. 
40. Chen YY, Chang YL, Shiau YY (2004) Accuracy of surgical drilling guide surgi guide system. IADR/AADR/CADR $82^{\text {nd }}$ General Session. Hawaii, USA, pp. 10-13.

41. Chen X, Yuan J, Wang C, Huang Y, Kang L (2010) Modular preoperative planning software for computer-aided oral implantology and the application of a novel stereolithographic template: A pilot study. Clin Implant Dent Relat Res 12(3): 181-193.

42. Jayme SJ, Muglia VA, de Oliveira RR, Novaes AB (2008) Optimization in multi-implant placement for immediate loading in edentulous arches using a modified surgical template and prototyping: A case report. Int Oral Maxillofac Implants 23(4): 759-762.

43. Papaspyridakos P, Lal K (2008) Complete arch implant rehabilitation using subtractive rapid prototyping and porcelain fused to zirconia prosthesis: A clinical report. J Prosthet Dent 100(3): 165-172.

44. Di Giacomo GA, Cury PR, de Araujo NS, Sendyk WR, Sendyk CL (2005) Clinical application of stereolithographic surgical guides for implant placement: Preliminary results. J Periodontol 76(4): 503-507.
45. Dörtbudak O, Haas R, Bernhart T, Mailath-Pokorny G (2001) Lethal photosensitization for decontamination of implant surfaces in the treatment of peri-implantitis. Clin Oral Implants Res 12(2): 104-108.

46. Khadra M, Rønold HJ, Lyngstadaas SP, Ellingsen JE, Haanaes HR (2004) Low-level laser therapy stimulates bone-implant interaction: An experimental study in rabbits. Clin Oral Implants Res 15(3): 325-332.

47. Stein A, Benayahu D, Maltz L, Oron U (2005) Low-level laser irradiation promotes proliferation and differentiation of human osteoblasts in vitro. Photomed Laser Surg 23(2): 161-166.

48. Kana JS, Hutschenreiter G, Haina D, Waidelich W (1981) Effect of lowpower density laser radiation on healing of open skin wounds in rats. Arch Surg 116(3): 293-296.

49. Guzzardella GA, Tigani D, Torricelli P, Fini M, Martini L, et al. (2001) Lowpower diode laser stimulation of surgical osteochondral defects: Results after 24 weeks. Artif Cells Blood Substit Immobil Biotechnol 29(3): 235244.

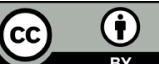

Creative Commons Attribution 4.0 International License

For possible submissions Click Here

\section{Submit Article}

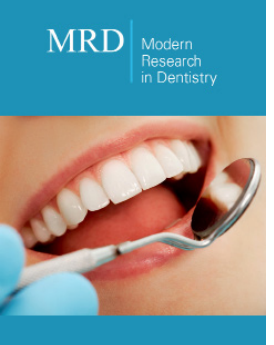

\section{Modern Research in Dentistry}

\section{Benefits of Publishing with us}

- High-level peer review and editorial services

- Freely accessible online immediately upon publication

- Authors retain the copyright to their work

- Licensing it under a Creative Commons license

- Visibility through different online platforms 